\title{
Graded (metric) tenses in embedded clauses: The case of South Baffin Inuktitut*
}

\author{
Midori Hayashi \\ Nagoya University
}

\author{
David Y. Oshima \\ Nagoya University
}

\begin{abstract}
This work discusses how tenses in South Baffin Inuktitut (SBI; the Eskimo-Aleut family), which are associated with remoteness specifications, are interpreted in embedded clauses. In SBI dependent clauses, the reference point for remoteness specifications may be, but is not necessarily, relativized (shifted) to a time other than external "now". For example, while the hodiernal past (marked by suffix -qqau) designates the day of utterance as its domain of coverage, it may not do so in a subordinate clause. Whether an embedded tense may and must be relativized with regard to remoteness depends on four factors: (i) whether the embedded tense is relativized with regard to temporal direction (the past-present-future opposition), (ii) what the type of the subordinate clause is, (iii) what the tense of the superordinate clause is, and (iv) what the tense of the subordinate clause is. The findings suggest that tense systems across languages may contrast not only with respect to under what circumstances shifting of the directional temporal reference point takes place, but also with respect to under what circumstances shifting of the reference point for temporal remoteness takes place.
\end{abstract}

Keywords: graded (metric) tense, the relative interpretation of tense, indexicality, embedded clauses, Inuktitut

\section{Introduction}

This paper examines how graded (metric) tenses in South Baffin Inuktitut (SBI; a variety of the Inuit languages, the Eskimo-Aleut family) are interpreted in embedded (dependent) clauses, and discusses the implications of the observed pattern on the general question of whether and under what conditions the reference point for

* This research was supported by grants of Ontario Graduate Scholarship (OGS), Northern Scientific Training Program (NSTP), and Social Sciences and Humanities Research Council of Canada (SSHRC). We are grateful to Alana Jones, Elizabeth Cowper, Diane Massam, Michela Ippolito, Lisa Matthewson, Christina Cuervo, and the reviewers and audience of SALT 27 for helpful comments and suggestions. Our special thanks go to late Saila Michael, who helped us as a native speaker consultant of SBI for many years. 
"remoteness specifications" may be shifted (relativized). ${ }^{1}$

All data presented in the current work are drawn from fieldwork conducted during the period of 2004-2014. The primary method of data collection was face-toface interviews with one native speaker of SBI; correspondences by e-mail with the same consultant were also used as a supplementary method. ${ }^{2}$

\section{2 (Two kinds of) the relative interpretation of embedded tenses}

\subsection{Relativization of the past-present-future opposition}

Tenses in embedded clauses may be interpreted relative to a time distinct from the time of utterance, thereby receiving a so-called "relative" interpretation. It is common, and possibly the norm, for the reference point relative to which the distinction between past, present, and future is made (henceforth, the directional reference point, or $t_{d}$ ) for a tense within the complement clause of an attitude/speech predicate to be the time of the secondary context (i.e., the context of the reported belief, utterance, etc.). In some languages, it is also possible for $t_{d}$ within some types of non-complement dependent clauses - i.e., adjunct and relative clauses - to match the time of the matrix eventuality (e.g., Kubota, Lee, Smirnova \& Tonhauser 2009; Oshima 2009, 2011; Ogihara \& Sharvit 2012).

\subsection{Relativization of remoteness specifications}

A good number of languages (perhaps some one third of languages with tense; Dahl \& Velupillai 2005; Botne 2012) have a graded (or metric) tense system, which involves multiple past, and/or multiple future, tenses with different remoteness specifications. A speaker of such a language might, for example, have to choose between a hodiernal ("today") past and a prehodiernal ("before today") past to describe a situation in the past in a felicitous manner. An interesting generallinguistic question, which has been scarcely explored in the literature, is: Can the reference point for remoteness specifications $\left(t_{r}\right)$ be relativized, too? Can a hodiernal past, for example, designate the day of the matrix eventuality, instead of the day of utterance, as its domain of coverage?

One might find it likely that $t_{d}$ and $t_{r}$ always match, shifting of one implying that of the other. Mucha's (2017: 25-28) observation on how the temporal (past) re-

1 Some materials in the present work are from the first author's unpublished dissertation (Hayashi 2011).

2 The consultant spent some formative years in Coral Harbour (on Southampton Island, a Kivalliq region). Whether and how this affected her competence of SBI is unknown, except that some remnants of the dialect of Inuktitut spoken in that region (closely related to SBI) were observed in her speech. 
moteness morphemes in Medumba (the Bantu family) are interpreted in complement clauses is consistent with this "strict matching" hypothesis. If strict matching of $t_{d}$ and $t_{r}$ holds across the board, the distinction of the two will be redundant and can be dismissed for descriptive purposes.

In theory, however, it is possible for only one of $t_{d}$ and $t_{r}$ to be shifted (relativized) while the other remains unshifted. (1) illustrates situations where (i) $t_{d}$ and $t_{r}$ are shifted together within an embedded clause, (ii) only $t_{d}$ is shifted, (iii) only $t_{r}$ is shifted, and (iv) neither is shifted.

$$
\begin{aligned}
& {\left[\mathrm{s} 1 \ldots \mathrm{T}_{1} \ldots\left[\mathrm{s} 2 \ldots \mathrm{T}_{2} \ldots\right] \ldots\right]\left(\mathrm{T}_{1} \text { and } \mathrm{T}_{2} \text { are graded tenses }\right)} \\
& \text { a. } t_{d 2}=t_{r 2} \neq \text { external "now" }\left(=t_{d 1}=t_{r 1}\right) \\
& \text { b. } t_{d 2} \neq t_{r 2}=\text { external "now" }\left(=t_{d 1}=t_{r 1}\right) \\
& \text { c. } t_{r 2} \neq t_{d 2}=\text { external "now" }\left(=t_{d 1}=t_{r 1}\right) \\
& \text { d. } t_{d 2}=t_{r 2}=\text { external "now" }\left(=t_{d 1}=t_{r 1}\right)
\end{aligned}
$$

In the following, we will demonstrate that in SBI dependent clauses $t_{d}$ and $t_{r}$ may diverge in ways corresponding to (1b).

\section{The tense system of South Baffin Inuktitut}

The SBI tense system consists of the present, the hodiernal past, the prehodiernal past, the hodiernal future, the posthodiernal future, and a handful of additional past/future tenses with marked meaning and of low frequency (Hayashi 2011; Hayashi \& Oshima 2015). The past and future tenses are coded with verbal suffixes, and the present tense is zero-marked.

$$
\begin{array}{ll}
\text { present: } & \emptyset \text { (no marking) } \\
\text { hodiernal past: } & \text {-qqau } \\
\text { prehodiernal past: } & \text {-lauq } \\
\text { hodiernal future: } & \text {-niaq } \\
\text { posthodiernal future: } & \text {-laaq }
\end{array}
$$

As a general rule, independent SBI clauses describing a past or future situation must contain one, and at most one, of the temporal suffixes (an exception is clauses with a modal suffix with future-oriented meaning; Hayashi 2011: 103-104); this justifies the treatment of these suffixes as grammatical tense markers, rather than mere temporal modifiers. ${ }^{3}$

3 Zero-marked punctual (achievement/semelfactive) verbs are interpreted as describing a situation in the recent past. There is evidence, however, that such verbs are present-tensed and receive the aspectual interpretation of perfect (Hayashi 2011: 24-28; Hayashi \& Oshima 2015: 778-780). 
By way of illustration, the semantic contribution of the hodiernal past marker -qqau in a root clause will roughly be as in (3b). ${ }^{4}$ We assume that a root clause denotes a propositional character, i.e., a function from contexts to functions from worlds to truth values; $P$ is the slot for the core meaning of the clause, e.g., "John's arriving", and $\tau$ represents the temporal trace function:

a. jaan tiki-qqau-juq.

John arrive-qqau-Part.3s

'John arrived (sometime within today).'

b. $\lambda P[\lambda c[\lambda w[\exists e[P(c)(w)(e) \wedge \tau(e)<\operatorname{Time}(c) \wedge \tau(e) \subseteq \operatorname{Day}(c)]]]]$

The semantic contribution of the hodiernal future -niaq can be taken to be the mirror image of (3b). ${ }^{5}$

a. jaan tiki-niaq-tuq.

John arrive-niaq-Part.3s

'John will arrive (sometime within today).'

b. $\lambda P[\lambda c[\lambda w[\exists e[P(c)(w)(e) \wedge \tau(e)>\operatorname{Time}(c) \wedge \tau(e) \subseteq \operatorname{Day}(c)]]]]$

It is plausible that the "antihodiernality" of -lauq (prehodiernal past) and -laaq (posthodiernal future) - the underlined components in (5b) and (6b) - is not lexically encoded, but is derived through pragmatic inference (Hayashi 2011; Hayashi \& Oshima 2015; see also Cable 2013).

a. jaan tiki-lauq-tuq.

John arrive-lauq-Part.3s

'John arrived (yesterday or earlier).'

b. $\lambda P[\lambda c[\lambda w[\exists e[P(c)(w)(e) \wedge \tau(e)<\operatorname{Time}(c) \wedge \neg[\tau(e) \subseteq \operatorname{Day}(c)]]]]]$

a. jaan tiki-laaq-tuq. John arrive-laaq-Part.3s

'John will arrive (tomorrow or later).'

b. $\lambda P[\lambda c[\lambda w[\exists e[P(c)(w)(e) \wedge \tau(e)>\operatorname{Time}(c) \wedge \neg[\tau(e) \subseteq \operatorname{Day}(c)]]]]]$

4 The abbreviations in glosses are: $1=$ first person; $3=$ third person; $3 \mathrm{R}=$ third person reflexive; Acc $=$ accusative case All $=$ allative $;$ Caus $=$ causative mood $;$ Conj $=$ conjunctive mood Loc $=$ locative case $; \mathrm{Neg}=$ negation; $\mathrm{p}=$ plural; Part $=$ participial mood; Poss $=$ possessum noun; $\mathrm{s}=$ singular; $\mathrm{Tr}=$ transitivizer; / $=$ transitive agreement (e.g., $1 \mathrm{~s} / 3 \mathrm{~s}=$ first person singular subject/third person singular object) or possessive agreement (e.g., 1s/s $=1$ st person singular possessor/singular possessum).

5 The form -niaq is also used as a modal marker, which has a future-oriented meaning but is not associated with a remoteness specification (Hayashi 2011: 98-103). See below. 
This supposition is motivated by the observation that -lauq and -laaq are the only possible choices in the case of "remoteness indeterminacy", e.g. as in (9).

(7) jaan uqaala-\{\#lauq-tuq/qqau-juq\} ullaaq.

John call- $\{$ lauq-Part.3s/qqau-Part.3s $\}$ this.morning

'John phoned this morning.'

(8) jaan uqaala-\{lauq-tuq/\#qqau-juq\} ippatsaq.

John call-\{lauq-Part.3s/qqau-Part.3s $\}$ yesterday

'John phoned yesterday.'

(9) (Situation: S(peaker) was away from home since yesterday morning. S comes home, and notices that a message from John is left on her answering machine. S wonders when he phoned, but the answering machine does not tell when.)

jaan uqaala-\{lauq-tuq/\#qqau-juq\}.

John call- $\{$ lauq-Part.3s/qqau-Part.3s $\}$

'John phoned.'

(adapted from Hayashi \& Oshima 2015: 789)

\section{SBI dependent clauses in which the directional reference point may be shifted}

Types of SBI dependent clauses in which $t_{d}$ may (or must) be shifted include the following:

(10) i. Complement clauses (marked with the "causative" mood), in which $t_{d}$ must be the time of the secondary context

ii. Purpose clauses (again, marked with the "causative" mood), in which $t_{d}$ must be the time of the matrix eventuality

iii.Conjunctive clauses (marked with the "conjunctive" mood), in which $t_{d}$ may be either "now" or the time of the matrix eventuality

Shifting of $t_{r}$, relative to which the "hodiernality" is determined, is possible too. Importantly, however, shifting of $t_{d}$ does not necessarily entail shifting of $t_{r}$; in consequence, sometimes a tense may be "partly absolute, partly relative" - or more specifically, "absolute with respect to remoteness yet relative with respect to temporal direction". To our knowledge, SBI does not allow dependent clauses where only $t_{r}$, and not $t_{d}$, is shifted; that is, shifting $t_{d}$ seems to be a prerequisite for shifting of $t_{r}$.

In the following three sections, we will consider the three types of dependent clauses in (10) in turn. 
Graded tenses in embedded clauses

\section{Complement clauses}

In SBI complement clauses, $t_{d}$ is invariably (obligatorily) shifted to the time of the secondary context (the time of the reported belief, utterance, etc.), like in such languages as Hebrew, Japanese, and Medumba (Ogihara \& Sharvit 2012; Mucha 2017). $t_{r}$, on the other hand, may remain to be external "now". Specifically, $t_{r}$ (i) must match external "now" in the "past-under-past" configuration, where the matrix and subordinate clauses are both past-tensed (cf. Cable 2015), and (ii) may be either external "now" or the time of the secondary context elsewhere.

\subsection{The past-under-past configuration}

(11) and (12) exemplify the past-under-past configuration, where the domain covered by hodiernal -qqau must be the day of the primary context, i.e., external "today" (henceforth TODAY for short). ${ }^{6}$ In (11), the time of the secondary context is prior to TODAY; this entails that the time of the eventuality described in the embedded clause (the subordinate eventuality, or $e_{s u b}$ for short) too is prior to TODAY, and thus that the use of -qqau is unacceptable. Notice that, if in (11a) $t_{r}$ in the embedded clause, to which the embedded occurrence of -qqau is anchored, could be shifted (to the time of the secondary context), its use would be possible. In (12), on the other hand, the time of $e_{s u b}$ is within TODAY, as well as within the day of the secondary context (TODAY* for short), and accordingly the use of -qqau is acceptable.

a. \#ippatsaq jaan uqa-lauq-tuq [miali ningaungma-qqau-ngmat yesterday John say-lauq-Part.3s Mary be.upset-qqau-Caus.3s ullaakut]. in.the.morning

(Yesterday John said that Mary was upset in the morning (yesterday).)

b. ippatsaq jaan uqa-lauq-tuq [miali ningaungma-lau-ngmat yesterday John say-lauq-Part.3s Mary be.upset-lauq-Caus.3s

ullaakut].

in.the.morning

'idem'

(12) a. miali uqa-qqau-juq [jaan aulla-qqau-ngmat ullaaq].

Mary say-qqau-Part.3s John leave-qqau-Caus.3s this.morning

'Mary said (today) that John left this morning.'

6 -lau is an allomorphic variant of -lauq. 
Hayashi and Oshima
b. ?miali uqa-qqau-juq [jaan aulla-lau-ngmat ullaaq].
Mary say-qqau-Part.3s John leave-lauq-Caus.3s this.morning
'idem'

The semantic contribution of the embedded occurrence of -qqau in (12a) can be represented as in (13); variables $c$ and $c^{\prime}$ are respectively linked to the secondary and primary contexts.

$$
\lambda P\left[\lambda c\left[\lambda w\left[\exists e\left[P(c)(w)(e) \wedge \tau(e)<\operatorname{Time}(c) \wedge \tau(e) \subseteq \operatorname{Day}\left(c^{\prime}\right)\right]\right]\right]\right]
$$

-qqau can thus be said to be an indexical expression that may simultaneously refer to two distinct contexts, which to our knowledge has not been reported elsewhere.

Somewhat unexpectedly, in the configuration where (i) TODAY is the same day as TODAY*, and (ii) $e_{s u b}$ is within TODAY(*) (the " $\tau\left(e_{s u b}\right) \subseteq$ TODAY/TODAY*" configuration for short), the use of -lauq in the complement clause is dispreferred but appears not to be entirely blocked; (12) is an instance of this configuration. Our consultant's judgments on (12b) and other discourse segments with an embedded nonhodiernal tense under the " $\tau\left(e_{\text {sub }}\right) \subseteq$ TODAY/TODAY*" configuration, including (19b), (28b), and (29b) below, were unstable, varying from full acceptability to downright unacceptability. The diacritic question marks on $(12 b) /(19 b) /(28 b) /(29 b)$ reflect this variability, rather than the elicited judgment on the example on a particular occasion. $^{7}$

While this is resonant with the aforementioned supposition that -lauq is not inherently associated with a remoteness specification, it is not clear to us why the "antihodiernality" of -lauq (and -laaq) is weaker in complement clauses than in root clauses (cf. (7)). It is interesting to ask whether a similar phenomenon is observed in other languages with a graded tense system.

\subsection{The past-under-future configuration}

When a past-tensed complement clause is embedded under a future-tensed clause, $t_{r}$ is optionally shifted to the time of the secondary context, and accordingly, the domain covered by -qqau can be either TODAY or TODAY*. This is evidenced by the observation that both -qqau and -lauq are fully acceptable in both (14) and (15).

(14) (Situation: S will go ice-fishing today. S will use her sister's boots without telling her, because she is away until tomorrow. When she comes home tomorrow, S will tell her that she used her boots.)
a. qauppat uqau-ti-laaq-tara
[atu-qqau-gakkit kamalu-ngit]. tomorrow say-Tr-laaq-Part.1s/3s use-qqau-Caus.1s/3p boot-Poss.3s/p

7 See Hayashi 2011: 145-166 for additional data and a fuller presentation. 
Graded tenses in embedded clauses

'Tomorrow, I will tell her that I used her boots.'

b. qauppat uqau-ti-laaq-tara [atu-lau-rakkit kamalu-ngit]. tomorrow say-Tr-laaq-Part.1s/3s use-lauq-Caus. $1 \mathrm{~s} / 3 \mathrm{p}$ boot-Poss.3s $/ \mathrm{p}$ 'idem'

(15) (Situation: S will go ice-fishing tomorrow. S will use her sister's boots without telling her, because she is away until tomorrow. When she comes home tomorrow night, $\mathrm{S}$ will tell her that she used her boots.)

a. qauppat uqau-ti-laaq-tara [atu-qqau-gakkit kamalu-ngit]. tomorrow say-Tr-laaq-Part.1s/3s use-qqau-Caus.1s/3p boot-Poss.3s/p 'Tomorrow, I will tell her that I used her boots.'

b. qauppat uqau-ti-laaq-tara [atu-lau-rakkit kamalu-ngit]. tomorrow say-Tr-laaq-Part.1s/3s use-lauq-Caus. 1s/3p boot-Poss.3s/p 'idem'

In (14a), the hodiernality requirement of -qqau is satisfied if $t_{r}$ is unshifted and remains to be external "now"; in (14b), on the other hand, the antihodiernality requirement of -lauq is satisfied if $t_{r}$ is shifted to the time of the secondary context. Conversely, in (15a), the hodiernality requirement of -qqau is satisfied if $t_{r}$ is shifted; in (15b), the antihodiernality requirement of -lauq is satisfied if $t_{r}$ is unshifted.

The relative order between $e_{s u b}$ and external "now" is not a relevant factor; in (16), which is similar to (14) in that $e_{s u b}$ belongs to TODAY but not to TODAY* but differs from (14) in that $e_{s u b}$ precedes external "now", too, both -qqau and -lauq are possible options.

(16) (Situation: S will go to John's office in Toronto tomorrow afternoon. John left for Vancouver this morning. So, when S goes to his office tomorrow, his secretary Mary will say that he left.)

a. qauppat miali uqa-laaq-tuq [jaan aulla-qqau-ngmat]. tomorrow Mary say-laaq-Part.3s John leave-qqau-Caus.3s

'Tomorrow, Mary will say that John left.'

b. qauppat miali uqa-laaq-tuq [jaan aulla-lau-ngmat]. tomorrow Mary say-laaq-Part.3s John leave-lauq-Caus.3s 'idem'

When the eventuality described in the complement clause falls neither within TODAY nor TODAY*, the use of -qqau is blocked.

(17) (Situation: S will go ice-fishing tomorrow. S will use her sister's boots without telling her, because she is away until the day after tomorrow. When she comes home the day after tomorrow, $\mathrm{S}$ will tell her she used her boots.) 
a. \#uqau-ti-laaq-tara [atu-qqau-gakkit kamalu-ngit]. say-Tr-laaq-Part.1s/3s use-qqau-Caus.1s/3p boot-Poss.3s/p

(I will her that I used her boots.)

b. uqau-ti-laaq-tara [atu-lau-rakkit kamalu-ngit]. say-Tr-laaq-Part.1s/3s use-lauq-Caus.1s/3p boot-Poss.3s/p

'I will her that I used her boots.'

This excludes the possibility that the remoteness specification of -qqau is invariably something like "not prior to TODAY".

The semantic contribution of -qqau within a complement clause under a futuretensed superordinate clause can be represented as in (18), where $c$ and $c^{\prime}$ are to be linked to the secondary and primary contexts, respectively.

$$
\begin{aligned}
& \lambda P[\lambda c[\lambda w[\exists e[P(c)(w)(e) \wedge \tau(e)<\operatorname{Time}(c) \wedge[\tau(e) \subseteq \operatorname{Day}(c) \vee \\
& \left.\left.\left.\left.\left.\tau(e) \subseteq \operatorname{Day}\left(c^{\prime}\right)\right]\right]\right]\right]\right]
\end{aligned}
$$

It was remarked above that in the " $\tau\left(e_{s u b}\right) \subseteq$ TODAY/TODAY $*$ " configuration, the use of -lauq in the complement clause is marginal. This holds not only when the matrix clause is past-tensed, as in (12), but also when the matrix clause is future-tensed, as in (19).

(19) (Situation: S went ice-fishing today. S used her sister's boots without telling her. She will come back tonight.)

a. unnuk uqau-ti-niaq-para [atu-qqau-gakkit kamalu-ngit]. tonight say-Tr-niaq-Part.1s/3s use-qqau-Caus. $1 \mathrm{~s} / 3 \mathrm{p}$ boot-Poss. $3 \mathrm{~s} / \mathrm{p}$

'Tonight, I will tell her that I used her boots.'

b. ?unnuk uqau-ti-niaq-para [atu-lau-rakkit kamalu-ngit]. tonight say-Tr-niaq-Part.1s/3s use-lauq-Caus.1s/3p boot-Poss.3s/p 'Tonight, I will tell her that I used her boots.'

In other words, the weakening of the "antihodiernality" of -lauq happens under a future-tensed matrix clause as well.

\subsection{The future-under-past and future-under-future configurations}

$t_{r}$ for a future tense in a complement clause is optionally shifted to the time of the secondary context, regardless of the tense of the matrix clause. In accordance with this, both -niaq and -laaq are fully acceptable in (20), (21), and (22). ${ }^{8}$

8 -nia and -laa are allomorphic variants of -niaq and -laaq. 
Graded tenses in embedded clauses

(20) (Situation: When S talked to Mary on the phone yesterday, she said: "I will call John tomorrow". S now tells John what Mary said.)

a. uqa-lauq-tuq [ilin-nut uqaalar-nia-rami]. say-lauq-Part.3s you-All phone-niaq-Caus.3Rs

'She said that she would call you.'

b. uqa-lauq-tuq [ilin-nut uqaala-laa-rami]. say-lauq-Part.3s you-All phone-laaq-Caus.3Rs

'idem'

(21) (Situation: When S talked to Mary on the phone yesterday, she said: "I will call John tonight'. S now tells John what Mary said.)

a. uqa-lauq-tuq [ilin-nut uqaalar-nia-rami]. say-lauq-Part.3s you-All phone-niaq-Caus.3Rs

'She said that she would call you.'

b. uqa-lauq-tuq [ilin-nut uqaala-laa-rami]. say-lauq-Part.3s you-All phone-laaq-Caus.3Rs

'idem'

(22) (Situation: Whenever S goes to John's office, he is not there and his secretary Mary says that he will come back shortly. Tomorrow $\mathrm{S}$ needs to go to his office again. $\mathrm{S}$ tells $\mathrm{H}$ (earer) what she thinks will happen.)

a. qauppat miali uqa-laa-mi-juq [jaan qai-gi-nia-ngmat]. tomorrow Mary say-laaq-again-Part.3s John come-again-niaq-Caus.3s

'Tomorrow Mary will say again that John will come back shortly.'

b. qauppat miali uqa-laa-mi-juq [jaan qai-gi-laa-ngmat]. tomorrow Mary say-laaq-again-Part.3s John come-again-laaq-Caus.3s

'idem'

One complication here is that the form -niaq, in addition to its use a hodiernal future marker, has a use as a modal marker of epistemic necessity with future orientation (and possibly also with a flavor of inferential evidentiality), which is not associated with a remoteness specification (Hayashi 2011: 110-117).

(23) (Situation: It is June now.)

tariuq siku-giir-niaq-tuqu utupiri-mit

ocean freeze-already-niaq-Part.3s October-Loc

'It must be the case that the ocean will be covered by ice in October.'

The polysemy of -niaq can be illustrated by the contrast between (24) and (25b). 
(24) (Situation: On Sunday mornings, John drinks either coffee or tea. In each week, his choice is completely random. It is early morning on Sunday, and John is still asleep.)

jaan kaapi-tur-niaq-tuq ullaaq uvvalunniit

John coffee-consume-niaq-Part.3s this.morning or

tii-tur-niaq-tuq ullaaq.

tea-consume-niaq-Part.3s this.morning

'John will have coffee this morning, or John will have tea this morning.' (true)

(OR: 'It must be the case that John will have coffee this morning, or it must be the case that John will have tea this morning.' (false))

(25) (Situation: John has the habit described above. It is Saturday now.)

a. jaan kaapi-tur-laaq-tuq qauppat uvvalunniit

John coffee-consume-laaq-Part.3s tomorrow or

tii-tur-laaq-tuq qauppat.

tea-consume-laaq-Part.3s tomorrow

'John will have coffee tomorrow, or John will have tea tomorrow.' '(true)

b. \#jaan kaapi-tur-niaq-tuq qauppat uvvalunniit

John coffee-consume-niaq-Part.3s tomorrow or

tii-tur-niaq-tuq qauppat.

tea-consume-niaq-Part.3s tomorrow

'It must be the case that John will have coffee tomorrow, or it must be the case that John will have tea tomorrow.' (false)

In the contexts of (24)/(25), the proposition: "John will have coffee on Sunday morning or John will have tea on Sunday morning" is known to be true, while a variant thereof with a strong modal, such as "It must be the case that John will have coffee on Sunday morning, or it must be the case that John will have tea on Sunday morning" or "John will surely have coffee on Sunday morning, or John will surely have tea on Sunday morning", is contextually known to be false. The observation that only (24), but not (25b) is judged as (having a reading that is) true entails that -niaq can be interpreted as a tense marker only in (24), where $e_{s u b}$ is within TODAY.

Due to the polysemy of -niaq, while the data in (20-22) demonstrate that $t_{r}$ may either be shifted or unshifted in the future-and-past configuration, evidence being the full acceptability of -laaq in (20) and (21), and that $t_{r}$ does not need to be shifted in the future-under-future configuration, evidence being the full acceptability of -laaq in (22), they do not reveal whether $t_{r}$ is shiftable in the future-under-future 
configuration (the availability of the form -niaq in (22a) does not guarantee the availability of -niaq as a tense marker).

To resolve this issue, we constructed discourse segments (26) and (27), where the readings on which -niaq is a modal marker lead to falsehood. Judgment elicitation revealed that (26) has a reading on which it is true and felicitous, while (27) does not. Since -niaq in (26) cannot be a modal marker on this reading, it must be concluded that it is used as a hodiernal future marker, which then implies that shifting of $t_{r}$ is possible in the future-and-future configuration too.

(26) (Situation: John drinks either coffee or tea on Friday afternoon. Emily is going to be his new secretary. Tomorrow, which happens to be Friday, is her first day. Tomorrow morning, at John's office, John's previous secretary, Mary, will teach her what to do, including how she is supposed to serve him drinks. Mary will say to Emily: "John drinks coffee or tea on Friday afternoon. Sometimes he asks for coffee, and sometimes he asks for tea. You cannot tell which until he actually asks you. So on Fridays, you have to make sure that you have both tea leaf and coffee beans ready".)

a. qauppat miali uqa-laaq-tuq [jaan kaapi-tur-nia-ngmat tomorrow Mary say-laaq-Part.3s John coffee-consume-niaq-Caus.3s unnusakkut uvvalunnit jaan tii-tur-nia-ngmat in.the.afternoon or John tea-consume-niaq-Caus.3s unnusakkut]. in.the.afternoon

'Tomorrow Mary will say that John will drink coffee in the afternoon or John will drink tea in the afternoon.'

OR: 'Tomorrow Mary will say that it must be the case that John will drink coffee in the afternoon or it must be the case that John will drink tea in the afternoon.' (false in the described situation)

b. qauppat miali uqa-laaq-tuq [jaan kaapi-tur-laa-ngmat tomorrow Mary say-laaq-Part.3s John coffee-consume-laaq-Caus.3s unnusakkut uvvalunnit jaan tii-tur-laa-ngmat in.the.afternoon or John tea-consume-laaq-Caus.3s unnusakkut]. in.the.afternoon

'Tomorrow Mary will say that John will drink coffee in the afternoon or John will drink tea in the afternoon.'

(27) (Situation: John drinks either coffee or tea on Friday afternoon. Emily is going to be his new secretary. Tomorrow, which happens to be Monday, is her first day. Tomorrow morning, at John's office, John's previous secretary, 
Mary, will teach her what to do, including how she is supposed to serve him drinks. Mary will say to Emily: "John drinks coffee or tea on Friday afternoon. Sometimes he asks for coffee, and sometimes he asks for tea. You cannot tell which until he actually asks you. So on Fridays, you have to make sure that you have both tea leaf and coffee beans ready".)

a. \#qauppat miali uqa-laaq-tuq [jaan kaapi-tur-nia-ngmat tomorrow Mary say-laaq-Part.3s John coffee-consume-niaq-Caus.3s

Friday-mit uvvalunnit jaan tii-tur-nia-ngmat Friday-mit].

Friday-Loc or John tea-consume-niaq-Caus.3s Friday-Loc

'Tomorrow, Mary will say that it must be the case that John will drink coffee on Friday or it must be the case John will drink tea on Friday.' (the only available interpretation; false in the described situation)

b. qauppat miali uqa-laaq-tuq [jaan kaapi-tur-laa-ngmat tomorrow Mary say-laaq-Part.3s John coffee-consume-laaq-Caus.3s unnusakkut uvvalunnit jaan tii-tur-laa-ngmat in.the.afternoon or John tea-consume-laaq-Caus.3s unnusakkut]. in.the.afternoon

'Tomorrow, Mary will say that John will drink coffee on Friday or John will drink tea on Friday.'

In the " $\tau\left(e_{s u b}\right) \subseteq$ TODAY/TODAY*" configuration, the use of -laaq in the complement clause is marginal (irrespective of what the tense of the matrix clause is). That is, the "antihodiernality" of -laaq is weakened in complement clauses, in the same way as that of -lauq.

(28) (Situation: This morning S went to John's office but he was not there. His secretary Mary told you that he would come back shortly.)

a. miali uqa-qqau-juq [jaan qai-gi-nia-ngmat].

Mary say-qqau-Part.3s John come-again-niaq-Caus.3s

'Mary said that John would come back shortly.'

b. ?miali uqa-qqau-juq [jaan qai-gi-laa-ngmat].

Mary say-qqau-Part.3s John come-again-laaq-Caus.3s

(idem)

(29) (Situation: S expects Jurgen to say, when she meets him at noon, that he will walk his dog sunny this afternoon.)

a. jurgen uqar-niaq-tuq [pisu-raja-qatigi-nia-ngmauk sunny]. Jurgen say-niaq-Part.3s walk-would-with-niaq-Caus.3Rs/3s Sunny

'Jurgen will say that he will walk Sunny.' 
Graded tenses in embedded clauses

b. ?jurgen uqar-niaq-tuq [pisu-raja-qatigi-laa-ngmauk sunny]. Jurgen say-niaq-Part.3s walk-would-with-laaq-Caus.3Rs/3s Sunny (idem)

\section{Purpose clauses}

In purpose clauses ("so that $p$ ") marked with the causative mood, $t_{d}$ is invariably relativized to the time of the eventuality described in the superordinate clause $\left(e_{\text {super }}\right)$. This, in conjunction with the inherent future-orientation of purposes (the intended situation always follows, rather than precedes, a purposeful action), implies that only a future tense may occur in a SBI purpose clause (cf. I praised him so that he was happy).

\subsection{Purpose clauses under a past-tensed superordinate clause}

When the superordinate clause is past-tensed, $t_{r}$ for a future tense in a purpose clause is obligatorily shifted to the time of $e_{\text {super }}$. That is, -niaq is chosen if $e_{\text {sub }}$ is within the day of $e_{\text {super }}$, and -laaq is chosen otherwise. The (un)acceptability of -laaq in $(30) /(31)$ endorses this generalization; -niaq in (31) is to be understood as -niaq as a modal marker.

(30) tuqsulaa-vigi-lauq-tara [\{tusaar-nia/\#tusaa-laa $\}$-ngmaanga $]$. yell-to-lauq-Part.1s/3s \{hear-niaq/hear-laaq\}-Caus.3s/1s

'I yelled so that he could hear me ( $\{$ on/\#after $\}$ the day I yelled).'

(31) (Situation: $\mathrm{S}$ is moving to a new apartment today. She phoned John a week ago so that he could help her today.)

uqaalak-vigi-lauq-tara uva-nnit phone-to-lauq-Part.1s/3s Pro.1s-Acc

[ikaju- $\{$ gunnar-nia/gunna-laa $\}$-ngmaanga ullumi]. help- $\{$ can-niaq/can-laaq $\}-$ Caus. $3 \mathrm{~s} / 1 \mathrm{~s} \quad$ today

'I phoned him, so that he could help me today.'

\subsection{Purpose clauses under a future-tensed superordinate clause}

When the superordinate clause is future-tensed, $t_{r}$ for the embedded future tense may be unshifted. This explains the acceptability of -laaq in (32) (cf. (30)).

(32) (Situation: Tomorrow $\mathrm{S}$ will see a man who has a hearing problem.) 
tuqsulaa-laaq-tunga [tusaa-\{ gunnar-nia/gunna-laa $\}$-ngmaanga].

yell-laaq-Part.1s hear-\{can-niaq/can-laaq $\}$-Caus. $3 \mathrm{~s} / 1 \mathrm{~s}$

'I will yell so that he can hear me.'

Due to the polysemy of -niaq, it is hard to determine whether $t_{r}$ can be shifted under a future-tensed superordinate clause or not. It seems sensible to assume that it can, however, as it leads to the following simple pattern: When $t_{d}$ is shifted within a future-tensed dependent clause (cf. $§ 5.3, \S 7$ ), it is possible but not necessary for $t_{r}$ to be shifted.

\section{Conjunctive clauses}

A conjunctive clause, which is marked by the conjunctive mood, stands in the semantic relation of logical conjunction with the superordinate clause. $t_{d}$ for a (present-, past-, or future-tensed) conjunctive clause may either be external "now" or be shifted to the time of $e_{\text {super }}$. Conjunctive clauses with shifted $t_{d}$ can be translated as "when P", "after P", etc., as the relatively interpreted embedded tense serves to specify the temporal order between $e_{\text {sub }}$ and $e_{\text {super }}$ (Hayashi 2011: 116-135).

When $t_{d}$ for a future-tensed conjunctive clause is shifted, $t_{r}$ may either remain to be external "now" or be shifted to the time of $e_{\text {super }}$. When $t_{d}$ for a past-tensed conjunctive clause is shifted, $t_{r}$ is doubly specified -i.e., the hodiernality requirement of -qqau must be satisfied both with respect to TODAY and the day of $e_{\text {super }}$.

\subsection{Past-tensed conjunctive clauses}

In conjunctive clauses with shifted $t_{d}$, intriguingly, -lauq is not subject to any sort of remoteness constraint. -qqau, on the other hand, can be used only when $e_{s u b}$ is both within TODAY and within the day of $e_{\text {sub }}-$ i.e., when both $e_{\text {sub }}$ and $e_{\text {super }}$ are within TODAY - as in (33) and (34).

(33) (Situation: Sam and John arrived today, at 2 p.m. and at 5 p.m. respectively.)

ullumi [sam tiki-\{qqau/lauq\}-tillugu] jaan tiki-qqau-juq. today Sam arrive-qqau/lauq-Conj.3s John arrive-qqau-Part.3s

'Today, after Sam arrived, John arrived.'

(34) (Situation: The weather forecast says that today it will rain early afternoon, but not in the evening. John will arrive around 7 p.m.)

ullumi jaan tiki-niaq-tuq [silalu-\{qqau/lauq $\}$-tillugu]. today John arrive-niaq-Part.3s rain-qqau/lauq-Conj.3s 
Graded tenses in embedded clauses

'Today, John will arrive after it rains.'

(35) (Situation: John will leave next week. Mary will leave today.)

jaan aulla-laaq-tuq [miali aulla-\{\#qqau/lauq $\}$-tillugu].

John leave-laaq-Part.3s Mary leave-qqau/lauq-Conj.3s

'John will leave after Mary leaves.'

(36) (Situation: Mary and John participated in a dance competition a week ago. John danced after Mary did.)

pingasuarusiulauqtumit [miali mumi-\{\#qqau/lauq\}-tillugu] jaan

last.week Mary dance-qqau/lauq-Conj.3s John

mumi-lauq-tuq.

dance-lauq-Part.3s

'Last week, after Mary danced, John danced.'

(37) (Situation: Mary and John will participate in a dance competition tomorrow. Mary will dance in the morning and John in the afternoon.)

qauppat [miali mumi-\{\#qqau/lauq\}-tillugu] jaan mumi-laaq-tuq. tomorrow Mary dance-qqau/lauq-Conj.3s John dance-laaq-Part.3s

'Tomorrow, after Mary dances, John will dance.'

That is, in a conjunctive clause with shifted $t_{d}$, the hodiernality requirement of -qqau is doubly enforced, both with respect to TODAY and to the day of $e_{\text {super }}$, as if $t_{r}$ were "copied", rather than shifted. ${ }^{9}$

\subsection{Future-tensed conjunctive clauses}

In conjunctive clauses where $t_{d}$ is shifted and $e_{\text {sub }}$ temporally follows $e_{\text {super }}$, -laaq cannot be used, and -niaq instead must be chosen, if both $e_{\text {sub }}$ and $e_{\text {super }}$ are within TODAY. ${ }^{10}$

9 One may take -qqau in a complement clause under a past-tensed superordinate clause, too, to be subject to a dual remoteness specification which requires that $e_{s u b}$ be both within TODAY and within TODAY* (see §5.1). Adding the latter condition does not lead to any empirical difference (i.e., is redundant), because, provided that both matrix and complement clauses are past-tensed, $e_{s u b}$ 's being within TODAY entails $e_{s u b}$ 's being within TODAY* (observe for example that " $\mathrm{X}$ said [that Y arrived today]." implies that the day of X's speech and the day when X said Y arrived are the same).

10 Conjunctive clauses in sentences like (38-41) have a semantic contribution similar to those of English before-clauses. When elicited to provide translations in English, however, our consultant tended to choose constructions like "when X is going to ...", "when X is supposed to ...", etc., instead of "before ...", for some reason unclear to us. 
(38) (Situation: Today, John came at 3 p.m. and it started raining at 5 p.m.)

ullumi jaan qai-qqau-tuq \{silalung-niaq/silalu-\#laaq\}-tillugu.

today John come-qqau-Part.3s \{rain-niaq/rain-laaq\}-Conj.3s

'Today, John came when it was going to rain.'

(39) (Situation: The weather forecast says that today it will start raining in the evening. John will come around 3 p.m.)

ullumi jaan qai-niaq-tuq \{silalung-niaq/silalu-\#laaq\}-tillugu.

today John come-niaq-Part.3s \{rain-niaq/rain-laaq $\}$-Conj.3s

'Today, John will come when it is going to rain.'

The choice of -laaq is not blocked by $e_{s u b}$ 's being within TODAY alone, or $e_{s u b}$ 's being within the day of $e_{\text {super }}$ alone.

(40) (Situation: Mary left yesterday, and John left today.)

ippatsaq miali aulla-lauq-tuq [jaan \{aullar-niaq/aulla-laaq\}-tillugu]. yesterday Mary leave-lauq-Part.3s John \{leave-niaq/leave-laaq\}-Conj.3s

'Yesterday, Mary left when John was going to leave.'

(41) (Situation: Mary arrived yesterday, and John will arrive today.)

miali tiki-lauq-tuq [jaan tiki-\{niaq/laaq $\}$-tillugu].

Mary arrive-lauq-Part.3s John arrive-niaq/laaq-Conj.3s

'Mary arrived when John was going to arrive.'

From the observed occurrence pattern of -laaq, it can be concluded that when $t_{d}$ for a future-tensed conjunctive clause is shifted, $t_{r}$ can but does not need to be shifted.

\section{Conclusion}

The observations made above - summarized in Table 1 - greatly expand the logical space of possible tense systems; tense systems may contrast not only with respect to (i) how many and what kinds of tenses they have and (ii) under what circumstances they allow shifting of $t_{d}$, but also (iii) with respect to the ways $t_{r}$ might vary. 
Graded tenses in embedded clauses

\begin{tabular}{lll}
\hline & Shifting of $t_{d}$ & Shifting of $t_{r}$ \\
\hline $\begin{array}{l}\text { Complement clauses } \\
\text { (a) past-under-past } \\
\text { (b) elsewhere }\end{array}$ & $\begin{array}{l}\text { obligatory } \\
\text { obligatory }\end{array}$ & $\begin{array}{l}\text { obligatory } \\
\text { optional }\end{array}$ \\
\hline $\begin{array}{l}\text { Purpose clauses } \\
\text { (a) future-under-past }\end{array}$ & obligatory & obligatory \\
(b) future-under-future & obligatory & optional \\
\hline $\begin{array}{l}\text { Conjunctive clauses } \\
\text { (a) past-under-X }\end{array}$ & optional & $\begin{array}{l}\text { If } t_{d} \text { is shifted, } t_{r} \text { is } \\
\text { obligatorily "copied". }\end{array}$ \\
(b) future-under-X & optional & $\begin{array}{l}\text { If } t_{d} \text { is shifted, } t_{r} \text { is op- } \\
\text { tionally shifted. }\end{array}$ \\
\hline
\end{tabular}

Table 1 Shiftability of $t_{d}$ and $t_{r}$ in the three kinds of dependent clauses

Two general patterns found across SBI dependent clause types are:

a. Shifting of $t_{r}$ is possible only when $t_{d}$ is shifted.

b. i. The past-tensedness of either the superordinate or subordinate clause tends to lead to the rigidity of $t_{r}$.

ii. The future-tensedness of either the superordinate or subordinate clause tends to lead to the flexibility of $t_{r}$.

We leave it to future research whether these patterns hold as universals or tendencies across languages with graded tenses.

\section{References}

Botne, Robert. 2012. Remoteness distinctions. In Robert I. Binnick (ed.), The Oxford Handbook of Tense and Aspect, 536-562. Oxford: Oxford University Press.

Cable, Seth. 2013. Beyond the past, present, and future: Towards the semantics of 'graded tense' in Gĩkũyũ. Natural Language Semantics 21. 219-276. doi:10.1007/s11050-012-9092-3.

Cable, Seth. 2015. Graded tenses in complement clauses: Evidence that future is not a tense. Poster presentation at North East Linguistic Society (NELS) 45.

Dahl, Östen \& Viveka Velupillai. 2005. Tense and aspect. In Martin Haspelmath, Matthew Dryer, David Gil \& Bernard Comrie (eds.), World Atlas of Language Structures, 266-272. Oxford: Oxford University Press. 
Hayashi, Midori. 2011. The structure of multiple tenses in Inuktitut. Toronto, Ontario: University of Toronto PhD dissertation.

Hayashi, Midori \& David Y. Oshima. 2015. How multiple past tenses divide the labor: The case of South Baffin Inuktitut. Linguistics 53. 773-808. doi:10.1515/ling-2015-0017.

Kubota, Yusuke, Jungmee Lee, Anastasia Smirnova \& Judith Tonhauser. 2009. On the cross-linguistic interpretation of embedded tenses. In Arndt Riester \& Torgrim Solstad (eds.), Sinn und Bedeutung (SuB) 13, 307-320. Stuttgart: Universität Stuttgart.

Mucha, Ann. 2017. Past interpretation and graded tense in Medumba. Natural Language Semantics 25. 1-52. doi:10.1007/s11050-016-9128-1.

Ogihara, Toshiyuki \& Yael Sharvit. 2012. Embedded tenses. In Robert I. Binnick (ed.), The Oxford Handbook of Tense and Aspect, 638-668. Oxford: Oxford University Press.

Oshima, David Y. 2009. Perspective, logophoricity, and embedded tense in Japanese. In Yukinori Takubo, Tomohide Kinuhata, Szymon Grzelak \& Kayo Nagai (eds.), Japanese/Korean Linguistics 16, 481-495. Stanford, CA: CSLI Publications.

Oshima, David Y. 2011. On the interpretation of toki-clauses: Beyond the absolute/relative dichotomy. Journal of East Asian Linguistics 20. 1-32. doi:10.1007/s10831-011-9071-6.

Midori Hayashi

Graduate School of Humanities

Nagoya University

Nagoya, Japan 464-8601

midori.hayashi@gmail.com
David Y. Oshima

Graduate School of Humanities

Nagoya University

Nagoya, Japan 464-8601

davidyo@nagoya-u.ac.jp 